\title{
Students' Accommodation and Academic Performance: The Case of Ho Technical University, Ghana
}

\author{
Justice Stephen Tetteh Zotorvie (MSc) \\ Lecturer, Department of Accounting and Finance \\ Faculty of Business and Management Studies, \\ Ho Technical University, Ghana
}

doi: 10.19044/esj.2017.v13n13p290 URL:http://dx.doi.org/10.19044/esj.2017.v13n13p290

\begin{abstract}
This study investigated the critical factors that influenced students' choice of residential accommodation facilities as well as the effect of accommodation type on academic performance in Ho Technical University, Ghana. Data for the study was collected through a questionnaire survey from purposively selected 200 respondents. The IBM Statistical Package for Social Sciences (SPSS) version 20 was used to analyse the data. Descriptive statistics were employed to determine the critical factors that influenced students' choice of residential accommodation facilities and Chi-Square Test was used to address the research hypothesis. The study revealed that proximity to lecture halls, spacious and well ventilated rooms; calm and peaceful environment, availability of study area, accommodation fee, and availability of electricity and water were the critical factors that influenced the students' choice of residential accommodation. The chi-square test revealed that there was no significant effect of accommodation type on the academic performance of students.
\end{abstract}

Keywords: Academic performance, Accommodation, Cumulative Grade Point Average (CGPA), Private hostels, Students

\section{Introduction}

Students' accommodation has been identified as one of the essential components of tertiary institutions. The availability of accommodation for students enables tertiary institutions to attract large number of students of different nationalities and backgrounds to pursue higher education (Kolawole \& Boluwatife, 2016). Onclin, (2014) noted that "tertiary institutions' involvement in accommodation was not just useful for attracting students; it would also influence student success, student retention rates, and student 
satisfaction”. Nimako \& Bondinuba, (2013) also identified accommodation as an important factor that enhances tertiary students' living and learning and suggested that adequate accommodation facilities be provided to students so that they could make the most of their educational opportunity.

Tertiary institutions have the responsibility to provide decent accommodation for students who successfully gain admission to purse various programmes of study. For government institutions, accommodation facilities are usually provided by the government. However, as result of high demand for tertiary education in recent times, governments of many countries are not able to adequately provide accommodation for students of tertiary institutions (Sharma, 2012). Consequently, other educational stakeholders have had to support government efforts, either in partnership with government or by solely providing private accommodation facilities for tertiary students on or off-campus (Centre for Global Education, 2002; Department for Education and Skills, 2003).

Ho Technical University has three halls of residence which provide accommodation for its students. These are the Adaklu Hall (mixed sex block) which can accommodate 452 students, Vodzi Hall (male block) and Acolatse Hall (female block) which can accommodate 92 and 172 students respectively. The total students' population of the University for the 2015/2016 academic year was about 3,910. Clearly, the three halls of residence of the university are insufficient to accommodate all the students. As a result, students who could not get rooms in the institution's halls of residence to lodge are compelled to look for accommodation in hostels built by private individuals around the university. Other students are left with no option than to come for lectures from their respective homes.

One worrying situation was that, some students upon admission were assured of vacancy in the halls of residence but declined the offer and went in for private hostels. Others accepted the offer but stayed in the facility for one or two semesters and moved later to private hostels.

Due to the important role that accommodation plays in the tertiary students' living and their academic pursue, any issue affecting students' choice of residential accommodation should not be disregard. This study, therefore, aimed to investigate the key factors that influenced students' choice of residential accommodation in Ho Technical University and to determine whether type of accommodation significantly affected the students' academic performance.

Ubong, (2001) had observed that even though students' accommodation is an important component of students' management, it has not been receiving adequate attention. The findings of this study may provide valuable information for university administrators and private hostel investors to be better aware of the factors that influence students' choice of accommodation 
so that they can provide the right residential accommodation to enhance high academic performance. The paper may also contribute to literature in the area of students' accommodation and how it affects academic performance in tertiary institutions especially in Ghana

\section{Literature Review}

\section{Factors that influence students' choice of residential accommodation}

The Oxford English dictionary defined accommodation as a place to live or a place of temporary dwelling. Accommodation is a place to live which is rented over a period of time during the course of pursuing a degree in the university as well as other services enjoyed during this time (Adu-Gyamfi, Brenya \& Lamptey, 2014). With respect to students' accommodation, (Owolabi, 2015) described it as a place where students reside within or outside the campus. Students residing within the houses on the campus are known as on-campus students, while those residing in housing outside the campus are known as off-campus students. According to Schrager (1986), "students' accommodation is more than just a place to live; it is an organization in which students are participants”. The provision of students' accommodation helps in catering for students' housing needs in accomplishing academic, living, and social goals during their study life span at the university (Hassanain, 2008).

Many researchers have discussed the different factors that influenced students' choice of residential accommodation in their works. Roche, Flanigan, Kenneth \& Copeland, (2010) for instance, examined the housing preferences of undergraduate students and reported that students desired housing options that fulfilled their high expectations for privacy and amenities. Moore, (2000) also found out that some students preferred offcampus accommodation to on-campus due to lack of privacy, noise and sharing of beds pace that is associated with on-campus accommodation. Therefore, they wanted to reside off-campus if they could secure a cheaper, decent and good housing that was in close proximity to campus with adequate facilities and could offer privacy. Wang \& Li, (2006) also identified convenience, security, price and proper layout as the major factors that influenced students' choice of residential accommodation. Reporting their work, Khozaei, Ayub, Hassan \& Khozaei, (2010) found the rental rates, distance from university facilities, room safety, room size, hostel security, and the hostel's other facilities as the most important factors that predict students' satisfaction with their hostels. In support of Khozaei et al., (2010) further studies also reported that proximity to campus, rental value of the property, facilities and amenities, convenience of the room, location, social contact and security are the most important factors that influence the accommodation preferences of student [Khozaeia, Ramayah \& Hassana, 
(2012); Kolawole \& Boluwatife, (2016)]. Oppewal, Poria, Ravenscroft \& Speller, (2005) on the hand identified that factors such as a mixed- or singlegender floor, view from the room, distance from campus, age of the building, and weekly rent were influential in students' housing preferences.

\section{Definition and Measurement of Academic Performance}

Academic performance is the outcome of education - the extent to which a student, teacher or an institution has achieved their educational goals (Annie, Howard \& Mildred, 1996). It has also been defined by Nabaseruka, (1997) as the knowledge and skills a student gained at school designated by test scores or marks assigned by teachers.

Students' academic performance is mostly measured by the Cumulative Grade Point Average (CGPA) (Gupta \& Maksy, 2014). CGPA shows the overall students' academic performance where it considers the average of all examinations' grade for all semesters during the tenure in university and it is believed that a higher CGPA is an indication of better learning (Ali, Jusoff, Ali, Mokhtar \& Salamat, 2009).This study used CGPA as the measure of students' academic performance. In Malaysia, researchers evaluated students' academic performance based on CGPA [Ervina \& Othman, (2005); Manan \& Mohamad, (2003) and Agus \& Makhbul, (2002)]. In addition, a study in the United States by Nonis \& Wright (2003) also evaluated students' performance based on CGPA.

\section{Effects of Accommodation on Students' Academic Performance}

Results of previous studies on the effect of accommodation on students' academic performance are somewhat mixed. Thompson, Samiratedu, \& Rafter, (1993) examined the effects of on-campus residence on first-time college students and found that freshman students who lived on campus had higher retention, a greater degree of academic progress, and higher academic performance. Agron, (1997) reported that studies in North America indicate that students in hall of residence hah higher Grade Point Averages, higher retention of their grades, are able to take on more credit hours and had the ability to form connections with the faculty members on campus. They also had a higher propensity to be more involved in students' leadership and politics on campus. Nabaseruka, (1997) also indicated that accommodation has a significant effect on the academic performance of students and in schools where accommodation facilities were good, the performance of students was also high compared to schools where accommodation facilities were poor. Other studies also found evidence of an increase in cumulative GPAs of students who lived in on-campus housing than their counterparts in off-campus housing. This was because students who lived on campus were more able to benefit from the university provided 
resources such as computer and information technology, university clubs, exercise facilities, and other extra-curricular activities [Araujo \& Murray, (2010); and Owolabi, (2015)].

On the contrary, Delucchi, (1993) examined a 'college town' where most students who lived off-campus and were in close walking distance of their lecture hall and university resources and found no statistically significant difference in academic achievement between students that live on campus and off-campus. Zhao \& Kuh, (2004) argued that the impact of residential accommodation on a university student's academic performance may also depend on how satisfied the student is with the type of living arrangement.

\section{Methodology}

\section{Target Population and Research Context}

The population of the study consisted of the second and final year students of Ho Technical University. This category of students were chosen because the researcher observed that unlike the first year students, they had knowledge of their CGPAs and were more experienced to aid in this research.

The origin of the university goes back to 1968. It was established as a Technical Institute with the primary objective of providing pre-technical education. In 1986, the Institute became a Polytechnic. It however continued to operate as second cycle institution, until 1993 when the Polytechnic was upgraded to a fully-fledged tertiary institution by the enactment of PNDC Law 321 and charged with the responsibility of training students in the technical and vocational skills to the Higher National Diploma (HND) level. The Polytechnics Act 2007 (Act 745) amended the PNDC Law 321 and further deepened the mandate of the Polytechnic to award degrees to the highest level. The passage of the technical universities ACT 2016 (Act 922), converted the Polytechnic to a Technical University with the mandate to award degrees, diplomas, certificates and other qualifications to the highest level in engineering, science and technology based disciplines, technical and vocational education and training, applied arts and related disciplines.

\section{Sampling and Data Collection}

A sample size of two hundred (200) student respondents was purposively selected to represent the population. The data was collected using printed questionnaires. The questionnaires were personally administered to respondents in May 2016. Participation in the survey was voluntary and the respondents were assured of confidentiality. 


\section{The questionnaire}

The questions were mostly close-ended questions but there were also a few open-ended questions to allow the respondents to express in their own words other factors that they believed might have influenced their choice of residential accommodation. The questionnaire was developed from the literature reviewed. The close- ended questions in the questionnaires sought the views of respondents on some statements about factors that could have influenced their choice of residential accommodation. Their views were captured on a 5-point likert scale with probability levels of $1=$ strongly disagree, 2 = disagree, 3 = undecided, 4-agree, 5 = strongly agree. Respondents were also asked to state whether they had ever stayed on campus and if yes, indicate the number of years they stayed in the University's Halls of Residence. Another question asked respondents to indicate their current type of residential accommodation and were further asked to indicate their CGPAs as the time of answering the questionnaire. In order to test the reliability and accuracy so as to remove ambiguity and biasness of the instrument the used to collect the data, a pilot study was done with twenty third year students at the University. The purpose of the pilot study was to find out whether the respondents understood the questions as the researcher has intended them to be understood and whether they answered them in the way the researcher expected them to be answered.

\section{Data analysis}

The data collected was first edited and subsequently analysed using IBM SPSS (version 20). Descriptive statistics mainly frequency tables, mean and standard deviations were used to rank the items in order to identify the major factors that influence students' choice of residential accommodation. The Kruskal-Wallis method was used to determine whether significant differences existed between the male and female respondents rating of the fourteen factors influencing respondents' choice of accommodation. Finally, the Pearson's Chi-Square was used to test for independency of accommodation types and students' academic performance.

\section{Results and Discussions}

\section{Socio-demographic information of respondents}

As shown in Table- 1 , out of the 200 respondents involved in this research, $52 \%$ were females and $48 \%$ were males. Also, majority (50.5\%) of the respondents was between the ages of 20-29 years, 30\% of them were below 20 years and $19.5 \%$ were in above 30 years age group. The analysis further revealed that $61 \%$ of the respondents were level 300 studens whiles $39 \%$ were level 200 students. The distribution of respondents by levels of education appeared to be skewed towards a particular level. Thus, $61 \%$ of the 
time, views leading to conclusion drawn from this research could be attributed largely to level 300 students. In terms of marital status, majority (89.5\%) of respondents were single while $10.5 \%$ of them were married. In terms of accommodation type, majority of respondents (64.5\%) lived in Private Hostels/Family Houses (non-residents) while $33.5 \%$ of them lived in the institution's halls of residence on campus.

Table -1: Demographic information of Respondents $(n=200)$

\begin{tabular}{ccc}
\hline Variables & Frequency & Percentage (\%) \\
\hline Gender & 96 & 48.0 \\
Male & 104 & 52.0 \\
Female & & \\
Age & 60 & 30.0 \\
Below 20 years & 121 & 50.5 \\
20-29 years & 19 & 19.5 \\
Above 30 years & & \\
Level of study & 78 & 39. \\
200 & 122 & 61 \\
300 & 179 & 89.5 \\
Marital Status & 21 & 10.5 \\
Single & & \\
Married & 129 & 64.5 \\
Accommodation type & 71 & 35.5 \\
Private Hostel/ Family House & & \\
Halls of Residence & & \\
\hline
\end{tabular}

Source: Field data (2016)

With the use of a five-point Likert scale, from 1= "strongly disagree" to 5= "strongly agree", respondents rated fourteen possible factors which influenced their choice of residential accommodation. A higher mean score for a statement indicated greater importance. Results presented in Table-2 below indicate that majority of respondents agreed that "proximity to lecture halls” ( $\mathrm{M}=4.43$, SD = 0.89) was the most influential factor that influenced their choice of residential accommodation. This was followed by "spacious and well ventilated rooms" $(\mathrm{M}=4.06, \mathrm{SD}=1.03)$. The next three major influential factors were "calm and peaceful environment”, “availability of study area" and "accommodation fee" with mean scores and standard deviations of $(\mathrm{M}=3.99, \mathrm{SD}=1.04),(\mathrm{M}=3.92, \mathrm{SD}=1.14)$ and $(\mathrm{M}=3.86$, $\mathrm{SD}=1.15)$ respectively. However, "availability of cafeteria” $(\mathrm{M}=2.81$, SD = 1.57), "availability of recreational facilities" $(\mathrm{M}=2.61, \mathrm{SD}=1.23)$ and "peer group influence" $(\mathrm{M}=2.13, \mathrm{SD}=1.18)$ were the least important factors that influenced the students' choice of residential accommodation. 
Table -2: Response to Factors that Influence Choice of Residence

\begin{tabular}{ccccccc}
\hline Factors & SA/A (\%) & $\mathrm{U}(\%)$ & $\mathrm{SD} / \mathrm{D}(\%)$ & Mode & Mean & Std. \\
\hline Availability of water and electricity & 70 & 5.83 & 29.17 & $\mathrm{~A}$ & 3.80 & 1.22 \\
Need for privacy & 49.17 & 16.67 & 34.17 & $\mathrm{~A}$ & 3.25 & 1.13 \\
Accommodation fee & 74.17 & 8.33 & 17.5 & $\mathrm{~A}$ & 3.86 & 1.15 \\
Peer group influence & 49.17 & 7.5 & 44.17 & $\mathrm{D}$ & 3.16 & 1.31 \\
Availability of recreational facilities & 26.67 & 20.83 & 52.5 & $\mathrm{D}$ & 2.61 & 1.23 \\
Availability of study area & 75.83 & 8.33 & 15.83 & $\mathrm{~A}$ & 3.92 & 1.14 \\
Security and safety issues of the hostel & 61.67 & 7.5 & 30.83 & $\mathrm{~A}$ & 3.48 & 1.25 \\
Spacious and well ventilated rooms & 80.83 & 7.5 & 11.67 & $\mathrm{~A}$ & 4.06 & 1.03 \\
Proximity to lecture halls & 88.33 & 5.0 & 6.67 & $\mathrm{SA}$ & 4.43 & 0.89 \\
Availability of cafeteria & 39.17 & 10.83 & 50 & $\mathrm{SD}$ & 2.81 & 1.57 \\
Access to transport & 45.83 & 11.67 & 42.5 & $\mathrm{SD}$ & 3.03 & 1.57 \\
Peer group influence & 14.17 & 13.33 & 72.5 & $\mathrm{D}$ & 2.13 & 1.18 \\
Number of inmates & 43.33 & 20.83 & 35.83 & $\mathrm{~A}$ & 3.09 & 1.18 \\
Calm and peaceful environment & 79.17 & 10.0 & 10.83 & $\mathrm{~A}$ & 3.99 & 1.04 \\
\hline
\end{tabular}

Values are the means on a 5-point likert scale (strongly disagree $=1$ and strongly agree $=5$ )

From Table-3 below, at a significant value of $\alpha=0.05$, it appears that none of the asymptotic is less than 0.05 . It therefore suggests that there is no significant difference between the male and female respondents rating of the fourteen factors influencing respondent's choice of residential accommodation.

Table-3: Significance Test for Samples from Male and Female Populations

\begin{tabular}{|c|c|c|c|}
\hline Accommodation Factors & Mann-Whitney U & Wilcoxon W & Asymp. Sig. (2-tailed) \\
\hline Availability of water and electricity & 4781 & 10241 & 0.589 \\
\hline Need for privacy & 4771 & 10231 & 0.565 \\
\hline Accommodation fee & 4753.5 & 9409.5 & 0.509 \\
\hline Peer group influence & 4409 & 9869 & 0.112 \\
\hline Availability of recreational facilities & 4900 & 10360 & 0.81 \\
\hline Availability of study area & 4592 & 10052 & 0.311 \\
\hline Security and safety issues of the hostel & 4575 & 9231 & 0.248 \\
\hline Spacious and well ventilated rooms & 4887.5 & 9543.5 & 0.76 \\
\hline Proximity to lecture halls & 4939.5 & 10399.5 & 0.88 \\
\hline Availability of cafeteria & 4895 & 9551 & 0.765 \\
\hline Access to transport & 4782 & 9438 & 0.539 \\
\hline Peer group influence & 4670.5 & 10130.5 & 0.41 \\
\hline Number of inmates & 4841.5 & 10301.5 & 0.691 \\
\hline Calm and peaceful environment & 4788.5 & 9444.5 & 0.604 \\
\hline
\end{tabular}

Source: Field data (2016)

\section{Analysis on Number of Years Respondents Stayed In the Halls of Residence}

In response to the question whether respondents had ever stayed on campus, Table- 4 shows that $74 \%$ of the respondents indicated that they did stay on campus and $26 \%$ stated that they did not stay on campus. 
Table- 4: Have You Ever Stayed On Campus?

\begin{tabular}{ccc}
\hline Response & Frequency & Percentage (\%) \\
\hline Yes & 148 & 74 \\
No & 52 & 26 \\
\hline TOTAL & 200 & 100 \\
\hline & Source: Field data (2016)
\end{tabular}

The next section displays the results obtained for the number of years respondents who said yes had stayed in the University's Halls of Residence. Table-5 shows that 70 (47.3\%) respondents have stayed in the halls of residence for only a year, 51 (34.5\%) respondents have stayed in the halls of residence for two years, followed by 27 (18.2\%) respondents who have stayed in the halls of residence for three (3) years. This means most students had moved from the halls of residence to private hostels or family house during their second or third year.

Table- 5: Number of Years Stayed In the Halls of Residence

\begin{tabular}{ccc}
\hline Responses & Frequency & Percentage (\%) \\
\hline 1 year & 70 & 47.3 \\
2 years & 51 & 34.5 \\
3 years & 27 & 18.2 \\
\hline TOTAL & 148 & 100 \\
\hline
\end{tabular}

Source: Field data (2016)

\section{Effects of Accommodation Type on Students' Academic Performance}

Table-6 shows that, 129 of the respondents representing 64.5\% stayed in Private Hostels/Family Houses while the remaining 71 of them (35.5\%) stayed in the institutes' halls of residence. Out of the total of 129 respondents who stayed in the Private Hostels/Family Houses, 15 (11.6\%) were in first class division; 74(57.4\%) were in the upper GPA division; 28(21.7\%) were in the lower GPA division; whiles the rest $12(9.3 \%)$ had pass GPAs. Also, out of the 71 respondents who stayed in the Halls of Residence, 10(14.1\%) were in the first GPA division; 34(47.9\%) were in upper GPA division; $18(25.3 \%)$ were in lower GPA division; whiles the rest $9(12.7 \%)$ had pass GPAs.

Table -6: Accommodation Type and Students' GPAs

\begin{tabular}{|c|c|c|c|c|c|}
\hline \multirow[b]{2}{*}{$\begin{array}{c}\text { Accommodation } \\
\text { type }\end{array}$} & \multicolumn{4}{|c|}{$\begin{array}{c}\text { GPA } \\
\text { Range }\end{array}$} & \multirow[b]{2}{*}{ Total } \\
\hline & $\begin{array}{l}4.0- \\
5.0\end{array}$ & 3.0-3.99 & 2.0-2.99 & $\begin{array}{l}1.5- \\
1.99 \\
\end{array}$ & \\
\hline Private Hostel/ Family House & 15 & 74 & 28 & 12 & 129 \\
\hline Hall of Residence & 10 & 34 & 18 & 9 & 71 \\
\hline Total & 25 & 108 & 46 & 21 & 200 \\
\hline
\end{tabular}

GPARange: 4.0-5.0-1 ${ }^{\text {st }}$ Class, $3.0-3.99-2^{\text {nd }}$ Upper, $2.0-2.99-2^{\text {nd }}$ Lower, and 1.5-1.99- Pass

A chi-square test was conducted to find out whether accommodation type significantly affected the students' academic performance (See Table- 7). 
Table -7: Chi-Square Test for Accommodation Type and Students' GPAs

\begin{tabular}{cccc}
\hline Chi-Square Test & Value & Df & Asymp. Sig. (2-tailed) \\
\hline Pearson Chi-Square & 7.045 & 5 & 0.317 \\
No of valid Cases & 200 & & \\
\hline
\end{tabular}

From Table-7, the p-value of 0.317 is greater than the significant value of 0.05 , indicating that the test was not significant with a chi-square value of 7.045 and a degree of freedom of 5 . Hence we failed to reject the null hypothesis and concluded that, type of accommodation does not significantly affect students' academic performance in Ho Technical University. That is, accommodation type and a student's CGPA are independent of each other. The CGPA of majority of students living in on-campus accommodation falls within the range of 3.0-3.99 (Second class upper division). The same applied to their counterparts who live in off-campus accommodation.

Thus a student's academic performance may depend more on other factors rather than the type of residential accommodation (whether offcampus or on-campus). The academic performance of students according to Raychaudhuri, Debnath, Sen \& Majumder, (2010) depends on a number of socio-economic factors such as the presence of teachers in school, students' attendance in the class, and their ability to effectively utilize the academic resources provided on campus. A non-resident student who lives closer to campus and effectively utilized the academic resources provided on campus can equally perform well academically.

\section{Conclusion and Policy Implications}

This study investigated the key factors that influenced students' choice of residential accommodation in Ho Technical University, Ghana. It also examined the effects of accommodation type on the students' academic performance. A survey was conducted on the second and final year students of the University. The study revealed that proximity to lecture halls, spacious and well ventilated rooms, calm and peaceful environments, availability of study area, accommodation fee and availability of electricity and water were the most important factors that influenced the students' choice of residential accommodation in Ho Technical University. It was also revealed that, accommodation type and students' academic performance were independent of each other. Thus, the students' academic performance depends on a number of socio-economic factors such the presence of teachers in school, the students' ability to attend classes regularly, and effectively utilize the academic resources provided on campus, and not necessarily the type of accommodation they occupy.

Based on the findings of this study, it is recommended that management of Ho Technical University should improve facilities in the 
various halls of residence to enhance the learning experience and academic performance of students. Also, the Ghana Government through the university's authority and private investors should provide more affordable hostels with adequate facilities to accommodate the ever increasing students' population of Ho Technical University.

\section{Limitation of the study}

This study focused mainly on the students of Ho Technical University; therefore, the findings of this study may not be generalized to other tertiary institutions due to the possibility of differences existing in the social and academic environments among institutional types. However, this study can be replicated in other universities and other tertiary institutions within Ghana and indeed in other universities around the world so that better generalizations could be made.

\section{References:}

1. Adu-Gyamfi, S., Brenya, E., \& Lamptey, E. E. L. (2014). Accommodation Reforms, Its Effects on students: A focus on Kwame Nkrumah University of Science and Technology from 1960 to 2013. Global Journal of Human-Social Science: (H) Interdisciplinary. Volume 14 Issue 2 .Version 1.0

2. Agron, J. (1997). Innovations in residence-life programming American School and University, 69, pp. 81-87

3. Agus, A., \& Makhbul, Z.K. (2002). An empirical study on academic achievement of business students in pursuing higher education: An emphasis on the influence of family backgrounds. Paper presented at International Conference on the Challenges of Learning and Teaching in a Brave New World: Issues and Opportunities in Borderless Education. Hatyai, Thailand.

4. Ali, N., Jusoff, K., Ali, S., Mokhtar N., \& Salamat A. S. A. (2009). The Factors Influencing Students' Performance at University Technology, MARA Kedah, Malaysia. Management Science and Engineering. ISSN 1913-0341 Vol.3 No.4

5. Centre for Global Education (2002). Rich World, Poor World: A Guide to Global Development. Retrieved from www.cgdev.org/files/2844_file_EDUCATON1.pdf

6. Delucchi, M. (1993). Academic Performance in a College Town. Education, 116

7. Ervina, A. \& Othman, M.N. (2005). Undergraduate students' performance: The case of University Malaya. Quality Assurance in Education. Vol. 13 No 4. pp. 329-343. 
8. Gupta, K., \& Maksy, M. M. (2014). Factors associated with student performance in an investments course: An empirical study. Journal of Finance and Accountancy. Volume 16

9. Hassanain, M.A. (2008). "Performance Evaluation of Sustainable Student Housing Facilities”. Journal of Facilities Management, 6: 212-225.

10. Khozaei, F., Ayub, N., Hassan, A.S. \& Khozaei Z. (2010). The Factors Predicting Students' Satisfaction with University Hostels: Case Study, Universiti Sains Malaysia. Asian Culture and History. ISSN 1916-9655 E-ISSN 1916-9663, Vol. 2, No. 2.

11. Khozaeia, F., Ramayah, T. \& Hassana, A. S. (2012). A Shorter Version of Student Accommodation. Preferences Index (SAPI). American Transactions on Engineering \& Applied Sciences. Volume 1 No.3. ISSN 2229-1652 eISSN 2229-1660.

12. Kolawole, O.A., \& Boluwatife, A.R. (2016). Assessment of the factors influencing students' choice of residence in Nigerian tertiary institutions. e-ISSN ISSN: 2289-6996

13. Manan, S.K., \& Mohamad, R. (2003). Kajian mengenai pencapaian akademik pelajar-pelajar di UiTM Shah Alam: Satu analisa perbandingan antara jantina. Social and Management Research Journal. Vol 1. No 1.

14. Moore, J. (2000). "Placing Home in Context". Journal of Environmental Psychology, 20: 207-217.

15. Nimako, S. G., \& Bondinuba F. K. (2013). Relative Importance of Students Accommodation Quality in Higher Education. Current Research Journal of Social Sciences 5(4): 134-142.ISSN: 2041-3238, e-ISSN: 2041-3246

16. Nonis, S.A., \& Wright, D. (2003). Moderating effects of achievement striving and situational optimism on the relationship between ability and performance outcomes of college students' research in higher education. Research in Higher Education. Volume 44, Number 3. pp. 327-346 (20)

17. Onclin, W. (2014). How Student Accommodation Impacts the International Student's Experience. Retrieved from http://www.eaie.org/blog/student-accommodation-impactsexperience/

18. Oppewal, H., Poria, Y., Ravenscroft, N., \& Speller, G. (2005). Student preferences for University accommodation: an application of the stated preference approach. London: Ashgate publishing limited.

19. Owolabi, B. O. (2015). The Effects of Students Housing on Academic Performance at the University of Ibadan in Nigerian. International 
Journal of Scientific \& Engineering Research. Volume 6, Issue 3, ISSN 2229-5518

20. Pedro de Araujo \& Murray J. (2010). Estimating the Effects of Dormitory Living on Students' Performance. The Social Science Research Network electronic library at: http://ssrn .com/ abstract $=1555892$.

21. Raychaudhuri, A., Debnath, M, Sen S. \& Majumder B. G. (2010). Factors Affecting Students' Academic Performance: A case study in Agartala Municipal Council Area. Bangladesh e-Journal of Sociology. Volume 7.

22. Roche, C. R. L., Flanigan, M. A., \& Kenneth Copeland, J. (2010). Student housing: trends, preferences and needs". Contemporary Issues in Education Research, 3(10), 45-50.

23. Schrager, R. H. (1986). The Impact of Living Group Social Climate on Student Academic Performance. Research in Higher Education, 25(3), 265-276.

24. Sharma, Y. (2012). Fast pace of higher education enrolment growth predicted to slow”. University world news Issue No: 213,

25. Sparkes, J. (1999). Schools, Education and Social Exclusion. CASE Paper 29, Centre for Analysis of Social Exclusion, London School of Economics, London.

26. Thompson, J., V. Samiratedu, \& Rafter J. (1993). The Effects of OnCampus Residence on First-Time College Students. NASPA Journal.

27. Ubong, B., (2001). Pupil personnel management in school: A new emphasis under the UBE scheme. Ahmadu Bello University Journal of Education

28. Wang, D., \& Li, S.-m. (2006). Socio-economic differentials and stated housing preferences in Guangzhou, China. Habitat International, 30, 305-326.

29. Zhao, C., \& Kuh, G. (2004). Adding Value: Learning Communities and Student Engagement”. Research in Higher Education, 45(2), 115-138. 